\title{
EFFECT OF DE-ASTRINGENCY METHOD AND MATURITY STAGES ON FRUIT QUALITY OF "COSTATA" PERSIMMON (Diospyros kaki L.) DURING SHELF LIFE
}

\section{Maha H. Abd El-Aziz}

Fruit Handling Research Department, Horticulture Research Institute, Agriculture Research Center (ARC), Giza, Egypt.

Corresponding author: mhaabdelaziz1975@gmail.com

\section{ABSTRACT}

Astringency removal is one of the most important factors that influence ripening; improve quality and shelf life of persimmon fruits. So, this study was carried out to evaluate the efficiency of some chemical treatments like ethephon, ethanol, calcium carbide and saturated lime on removal astringency of fruits harvested at two dates and its influence on fruit quality parameters during shelf life at room temperature. Fruit harvested at two dates (50 and 75\% color) were dipped in tap water for 5 days as control, saturated lime $\left(\mathrm{Ca}(\mathrm{OH})_{2}\right)$ for 5 days, ethephon at 500 or 750 ppm for 5 min, ethanol at 25 or $30 \%$ for 5 min and fruits exposed to gases resulted from mixing calcium carbide $\left(\mathrm{CaC}_{2}\right)$ at 10 or $20 \mathrm{~g}+$ $40 \mathrm{ml}$ water in closed chamber for $24 \mathrm{~h}$ and then stored at room temperature $23 \pm 1{ }^{\circ} \mathrm{C}$ and $60 \pm 5 \%$ RH for 15 days.

The obtained results showed that ethephon at 750 ppm for $5 \mathrm{~min}$ and calcium carbide at $20 \mathrm{~g}+40$ water had superior effect in reducing fruit weight loss $\%$, decay \%, total tannins and maintains firmness with increasing soluble solid content (SSC \%) and enhancing ripening process than other treatments in both harvesting stages used. Since, these treatments were more effective to remove fruit astringency through reducing tannin content. In general, ethephon at 750ppm and calcium carbide at $20 \mathrm{~g}$ treatments were effective in maintaining firmness, titratable acidity, ascorbic acid and soluble solids content in "Costata" persimmon fruits for 15 days of shelf life and removes the astringency. Moreover, the second picking date (75\% color) was more suitable for maintaining the above mentioned quality characters.

Conclusively, it could be recommended to harvest Costata persimmon fruits at $75 \%$ coloration and use one of the above mentioned treatments for removing the astringency with maintains the quality during shelf life.

Key words: Ethephon, Ethanol, Calcium, Kaki, Fruit firmness, Astringency, Decay, ripening 


\section{INTRODUCTION}

Japanese persimmon (Diospyros kaki, L.) is one of the most promising deciduous fruit species in Egypt, due to its low chilling requirements, adapts to the warm climate and increasing demands of local consumption (Ennab et al., 2018). Moreover, persimmon fruit is a good source of some bioactive compounds like ascorbic acid, tocopherol, carotenoids, polyphenols, dietary fibre, tannins and pectin, in addition to protein, lipids, carbohydrate, vitamins and minerals such as potassium, magnesium, zinc, iron, copper and manganese (Yaqub et al., 2016 and Gautam et al., 2020).

So, orchards of persimmon increased rapidly and cultivation spreads in many areas in Egypt. Such extension in cultivated area encourages establishing more studies to finding out a good and suitable solutions to the problems of persimmon farmers. Persimmon varieties categorized into two different groups: astringent and non-astringent varieties. The astringent varieties consist of high levels of soluble tannins while the non-astringent varieties contain small amount of tannins (Sato and Yamada 2016, Das and Eun 2020 and Vilhena et al., 2020).

Costata is the most widely grown astringent cultivar in Egypt. Therefore, the main problem facing persimmon growers are that fruit does not leave to ripe on the tree, but it needs to artificial ripening for commercial production and marketing. Some chemical substances like ethephon, ethanol, calcium carbide and carbon dioxide has been used to remove astringency content of fruits and improving fruit quality, besides maintaining fruit firmness and prolonging shelf life of persimmon fruits (Taira et al., 1999, Ahmed and Sobieh 2007, ElBadawy 2007 and Tessmer et al., 2016). In this respect, Abd El-Wahab et al., (2017) reported that, $\mathrm{CO}_{2}$ at $80 \%$ treatment was more effective and faster than Ethrel or Calcium carbide treatments in attaining a high taste score as a response to its pronouncing effect in removing astringency from Costata persimmon fruits than other treatments, also the lowest value of fruits firmness was associated with Ethrel and Calcium Carbide treatment. Moreover, El-Kady et al., (2008) indicated that, Ethephon at $750 \mathrm{ppm}$ was superior effect for reducing fruit firmness and total tannins with increasing total soluble solids than dipping fruits in 500 or $1000 \mathrm{ppm}$, in addition, ethanol application at $25 \%$ was suitable to accelerate fruit ripening with increasing soluble solids than dipping fruits in $50 \%$ concentration. Also, El-Badawy (2007) concluded that ethephon and calcium carbide were more effective to remove fruit astringency through reducing tannin content and maintain fruit quality of Costata persimmon. 
Therefore, this study aimed to evaluate the influence of maturity stage of "Costata" persimmon fruit and some chemical substances on efficiency of the astringency removal process and its influence on maintenance of fruit quality during shelf life period.

\section{MATERIALS AND METHODS}

The present study was carried out during 2019 and 2020 seasons on fruits harvested from 11 years old "Costata" persimmon trees (Diospyros kaki, L.) budded on (Diospyros lotus) rootstock, planted at $4 \times 4$ meter apart in a private orchard at Al-Gharbia governorate, Egypt. The fruits were harvested at two maturity stage, the first one $\left(\mathrm{P}_{1}\right)$ was done when the fruit peel reached $50 \%$ of color, after 157 and 155 days from full bloom in both seasons, respectively and the second one $\left(\mathrm{P}_{2}\right)$ when peel reached $75 \%$ of color, after 164 and 162 days from full bloom in both seasons, respectively, fruit color at picking dates were determining according to Japanese color chart (Ebert and Gross, 1985). Fruit samples in each picking date were selected for uniform size, color and free from physical injuries, insect attack and damages. Fruit samples were directly translocate to the laboratory of Sakha Horticulture Research Station, Kafr El-Sheikh governorate, cleaned, and washed with tap water, dipped in $2 \%$ boric acid for 2 minutes (surface-sterilized) and air dried with an electrical fan. Six fruits were taken to determine picking date quality parameters at each maturity stage. Thereafter, 192 fruits in each picking stage were divided into eight groups to receive one of the following artificial ripening treatments: control (dipping in tap water), saturated lime (dipping in $\mathrm{Ca}(\mathrm{OH})_{2}$ solution), ethephon at 500 and $750 \mathrm{ppm}$ (dipping in ethephon at 500 or $750 \mathrm{ppm}$ for $5 \mathrm{~min}$ ), ethanol at 25 and $30 \%$ (dipping in ethanol solution at 25 or $30 \%$ for $5 \mathrm{~min}$ ), calcium carbide 10 and 20 (fruits exposed to the gases resulted from the interaction between calcium carbide $\left(\mathrm{CaC}_{2}\right)$ at 10 or $20 \mathrm{~g}+40 \mathrm{ml}$ water in a closed chamber for 24 hour). The treatments were done as combinations between each maturity stage and chemical substance. The experimental design was complete randomized design, in three replicates was carried out to evaluate the effect of chemical treatments combined with maturity stage on efficiency of the astringency removal process and its influence on maintenance of fruit quality after 3, 5, 10 and 15 days of shelf life at room temperature.

\section{Preparation the artificial ripening treatments Saturated lime}

Persimmon fruits were soaked in a solution of calcium hydroxide $(\mathrm{Ca}$ $\left.(\mathrm{OH})_{2}\right)$ and water at $1: 10 \mathrm{w} / \mathrm{v}$, respectively for 5 days as recommended by Ryerson (1927). 


\section{Calcium carbide $\left(\mathrm{CaC}_{2}\right)$}

Persimmon fruits were exposed to the gases that resulted from calcium carbide $\left(\mathrm{CaC}_{2}\right)$ mixed with water in a closed chamber $\left(8 \mathrm{~m}^{3}\right)$ for 24 hour at 20$25^{\circ} \mathrm{C}$ as described by El zayat et al (2004). This treatment was done at two concentrations of $\mathrm{CaC}_{2}(10 \mathrm{~g}+40 \mathrm{ml}$ of water $)$ and $(20 \mathrm{~g}+40 \mathrm{ml}$ of water $)$.

\section{Ethephon method}

Persimmon fruits were dipped in ethephon solution (2- chloroethyl phosphonic acid) at concentration of 500 and 750 ppm for $5 \mathrm{~min}$.

\section{The treatments were arranged as follow:}

$\mathrm{T}_{1}$ : Fruits of $\mathrm{P}_{1}$ dipped in tap water for 5 days (control).

$\mathrm{T}_{2}$ : Fruits of $\mathrm{P}_{2}$ dipped in tap water for 5 days (control).

$\mathrm{T}_{3}$ : Fruits of $\mathrm{P}_{1}$ dipped in saturated lime for 5 days.

$\mathrm{T}_{4}$ : Fruits of $\mathrm{P}_{2}$ dipped in saturated lime for 5 days.

$\mathrm{T}_{5}$ : Fruits of $\mathrm{P}_{1}$ soaked in ethephon at $500 \mathrm{ppm}$ for $5 \mathrm{~min}$.

$\mathrm{T}_{6}$ : Fruits of $\mathrm{P}_{2}$ soaked in ethephon at $500 \mathrm{ppm}$ for $5 \mathrm{~min}$.

$\mathrm{T}_{7}$ : Fruits of $\mathrm{P}_{1}$ soaked in ethephon at $750 \mathrm{ppm}$ for $5 \mathrm{~min}$.

$\mathrm{T}_{\mathbf{8}}$ : Fruits of $\mathrm{P}_{2}$ soaked in ethephon at $750 \mathrm{ppm}$ for $5 \mathrm{~min}$.

T9: Fruits of $P_{1}$ soaked in ethanol at $25 \%$ solution for $5 \mathrm{~min}$.

$\mathrm{T}_{10}$ : Fruits of $\mathrm{P}_{2}$ soaked in ethanol at $25 \%$ solution for $5 \mathrm{~min}$.

$\mathrm{T}_{11}$ : Fruits of $\mathrm{P}_{1}$ soaked in ethanol at $30 \%$ solution for $5 \mathrm{~min}$.

$\mathrm{T}_{12}$ : Fruits of $\mathrm{P}_{2}$ soaked in ethanol at $30 \%$ solution for $5 \mathrm{~min}$.

$\mathrm{T}_{13}$ : Fruits of $\mathrm{P}_{1}$ exposed to calcium carbide $\left(\mathrm{CaC}_{2}\right)$ at $10 \mathrm{~g}+40 \mathrm{ml}$ water for $24 \mathrm{~h}$.

$\mathrm{T}_{14}$ : Fruits of $\mathrm{P}_{2}$ exposed to calcium carbide $\left(\mathrm{CaC}_{2}\right)$ at $10 \mathrm{~g}+40 \mathrm{ml}$ water for $24 \mathrm{~h}$.

$\mathrm{T}_{15}$ : Fruits of $\mathrm{P}_{1}$ exposed to calcium carbide $(\mathrm{CaC} 2)$ at $20 \mathrm{~g}+40 \mathrm{ml}$ water for $24 \mathrm{~h}$.

$\mathrm{T}_{16}$ : Fruits of $\mathrm{P}_{2}$ exposed to calcium carbide $(\mathrm{CaC} 2)$ at $20 \mathrm{~g}+40 \mathrm{ml}$ water for $24 \mathrm{~h}$

Samples from fruits exposed to above treatments (six fruits per treatment) were taken to determine fruit quality parameters after 3 days from treatments date. The remaining fruits were packed in ventilated plastic bags and hold in carton boxes ( $40 \times 25 \times 15 \mathrm{~cm}$ dimensions). Each treatment was represented by three carton boxes for each date. Each carton box contains six of "Costata" persimmon fruits. All boxes were stored at room temperature $23 \pm 1^{\circ} \mathrm{C}$ and $60 \pm$ $5 \% \mathrm{RH}$ for 15 days. During shelf life period, the fruit quality variables were measured at five day intervals as follow:

\section{Weight loss (\%):}

"Costata" persimmon fruits were weighed at zero time (before storage) and reweighted again at 5 day intervals during shelf life period. Weight loss was calculated according to the following equation: 
Fruit weight loss $\%=\left(\mathrm{W}_{0}-\mathrm{W}_{\mathrm{S}}\right) / \mathrm{W}_{0} \times 100$

Where, $\mathrm{W}_{0}=$ Fruit weight before treatment. $\mathrm{Ws}=$ Fruit weight after each shelf life periods.

\section{Fruit decay (\%):}

Fruit decay $\%$ was determined by calculating the number of decayed fruits in the sampling date and expressed as a percentage of fruit decay according to the following equation:

Fruit decay $\%=\{$ NO. of decayed fruits $\div$ Initial NO. of stored fruits $\} \times 100$

\section{Fruit firmness (Ib/inch ${ }^{2}$ ):}

Fruit firmness was examined in two sides of the fruit using Effigi pressure tester (mod. Ft327).

\section{Total tannins content ( $\mathrm{mg} / 100 \mathrm{ml})$ :}

Total tannins was determined in fruit juice by titrating $5 \mathrm{ml}$ of juice against $0.1 \mathrm{~N}$ of potassium permanganate $\left(\mathrm{KMnO}_{4}\right)$ using indigo-carmine as indicator according to A.O.A.C., (1990). The results were calculated as $\mathrm{mg}$ per $100 \mathrm{ml}$ juice.

\section{Fruit carotenoids content $(\mathrm{mg} / 100 \mathrm{ml})$ :}

Carotenoids content was determined using colorimetric method described by Holm (1954) and Wettstein (1957).

\section{Soluble solids content (\%):}

Soluble solid content (SSC \%) of persimmon fruits was recorded with the help of hand refractometer.

\section{Titratable acidity (\%):}

The acidity $\%$ of the fruit juice was estimated by titrating against standard alkali solution $(0.1 \mathrm{~N} \mathrm{NaOH})$ with phenolphthalein indicator and expressed as percentage of malic acid/100 $\mathrm{ml}$ of juice according to A.O.A.C., (1990),

8. SSC/acid ratio: SSC/acid ratio was calculated.

9. Ascorbic acid $\mathbf{~ m g / 1 0 0 ~} \mathbf{~ m l}$ juice:

Ascorbic acid was determined by using 2, 6 dichlorophenol indophenol pigment according to Rangana, (1977).

\section{Statistical analysis:}

The experiment treatments were arranged as complete randomized design. The data was analyzed using analysis of variance by MSTATC software program according to Snedecor and Cochran (1990) and treatment means were compared by using Duncan multiple range tests at 5\% level according to Duncan (1955). 


\section{RESULTS AND DISCUSSION}

\section{Weight loss (\%):}

Data in Table 1 shows the changes in weight loss \% of "Costata" persimmon fruits harvested at different maturity stages and exposed to some chemical treatments for removal astringency substances during 2019 and 2020 seasons. The results revealed that as the shelf life period progressed the percentage of weight loss was increased from 4.49 to9.17 and 4.78 to $9.40 \%$ after 15 days of shelf life in both seasons, respectively. Also, all chemical treatments showed a significant increase in fruit weight loss percentage compared to untreated fruits (control). Similar results were obtained by Rouhani et al., (1975) and Ramin and Tabatabaie (2003) they reported that weight loss of persimmon fruit was significantly affected by the stage of maturity under short term storage.

The highest percentage weight loss was observed in fruits of second maturity stage that exposed to calcium carbide $20 \mathrm{~g}$ treatment followed by ethephon at $750 \mathrm{ppm}$ and ethephon at $500 \mathrm{ppm}$ treatment in the first seasons. By the second one the highest weight loss $\%$ was associated with fruits of both maturity stages that treated with ethephon at 500 and $750 \mathrm{ppm}$ and calcium carbide at 10 and $20 \mathrm{~g}$ after 15 days in shelf life. On the other hand, the lowest percentage of weight loss was observed in untreated fruits of first maturity stage (control) in both seasons. Generally, the results indicated that exposure to some chemical treatments for removal astringency substances were significantly effective in weight loss percentages of "Costata" persimmon fruits in both maturity stages. In this respect, fruit harvested at $50 \%$ colored or at $75 \%$ and dipped in tap water for five days gave the lowest fruit weight loss percentage, followed by those dipped in saturated lime for five days. Similar results were obtained by Kou et al., (2020) on some persimmon cultivars. In this respect, Kamal and Rabeh (1989) revealed that "Costata" persimmon fruits soaked in ethephon solutions at concentrations of 500, 1000 and $2000 \mathrm{ppm}$ exhibited higher weight loss than those soaked in tap water (control). The loss of water from fresh fruit after harvest is a serious problem, causing shrinkage and weight loss. In this line, El-Badawy (2007) showed the role of chemical substances (ethephon and calcium carbide) in increasing weight loss of persimmon fruits may be due to increasing respiration rate and accelerating fruit ripening which known as ripe fruits lose their moisture content more quickly than unripe ones. 
Table 1: Effect of removal astringency method and maturity stage on weight loss $(\%)$ of "Costata" persimmon fruits during shelf life periods in 2019 and 2020 seasons

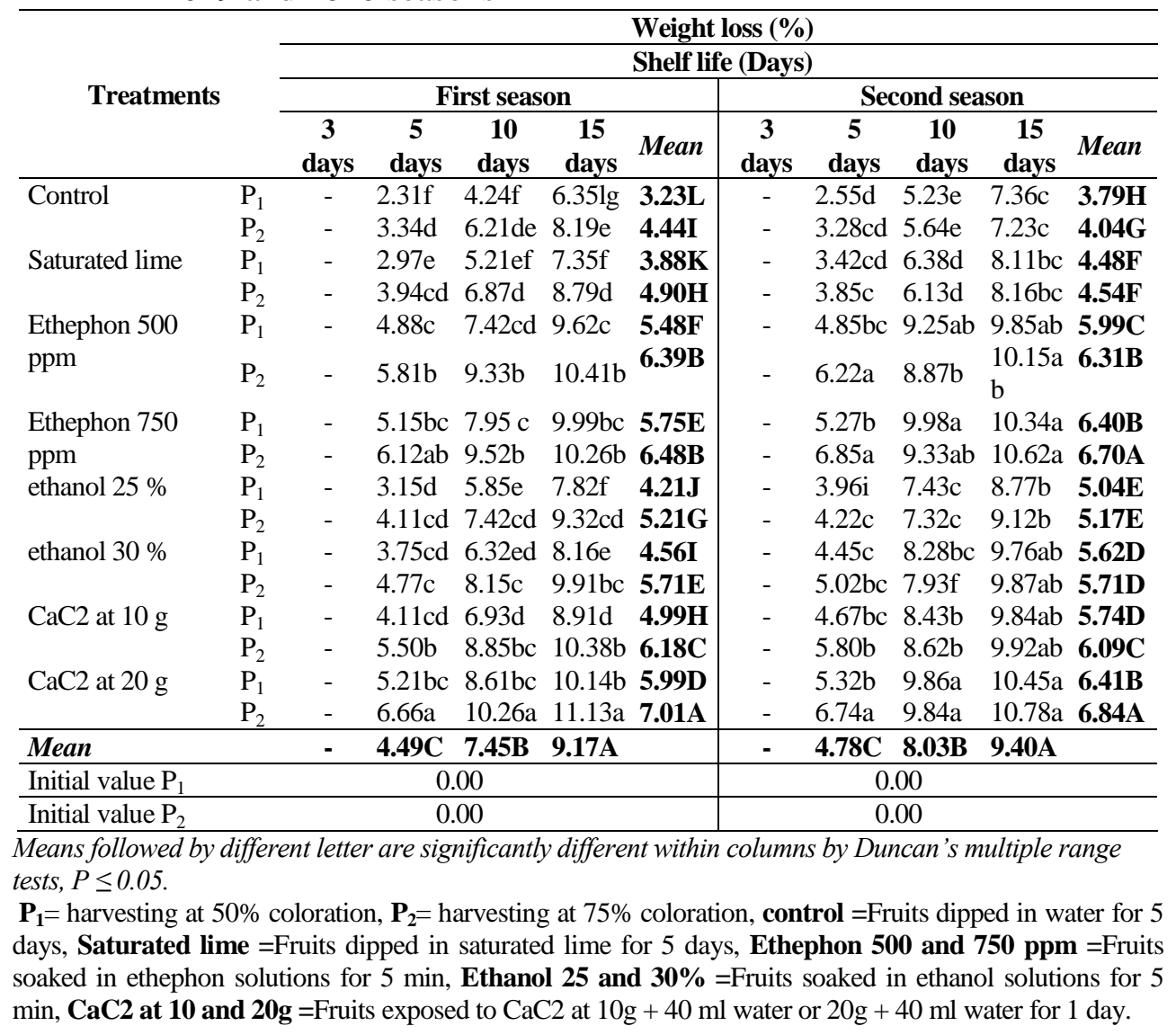

\section{Fruit decay (\%):}

Data presented in Table 2 show the effect of maturity stages and exposure to some chemical treatments on fruit decay percentage of "Costata" persimmon during shelf life period in 2019 and 2020 seasons. The results showed that fruit decay percentage was gradually increased with increasing shelf life since; it rose from 0.00 to 4.75 and 0.00 to $4.78 \%$ after 15 days of shelf life in both seasons, respectively. Also, results showed that advanced maturity of fruit promotes decay during shelf life.

Also, data in the same Table (2) reveal that, a significantly higher fruit decay $\%$ was recorded in fruits that harvested in second date $\left(\mathrm{P}_{2}\right)$ and treated by ethanol $25 \%$ after 10 and 15 days of shelf life. These results were true in both seasons. Anyhow, ethanol at 25\% treatment produced the highest fruit decay percentage as compared with the other treatments especially in second maturity 
Table 2: Effect of removal astringency method and maturity stage on fruit decay $(\%)$ of "Costata" persimmon fruits during shelf life period in 2019 and 2020 seasons

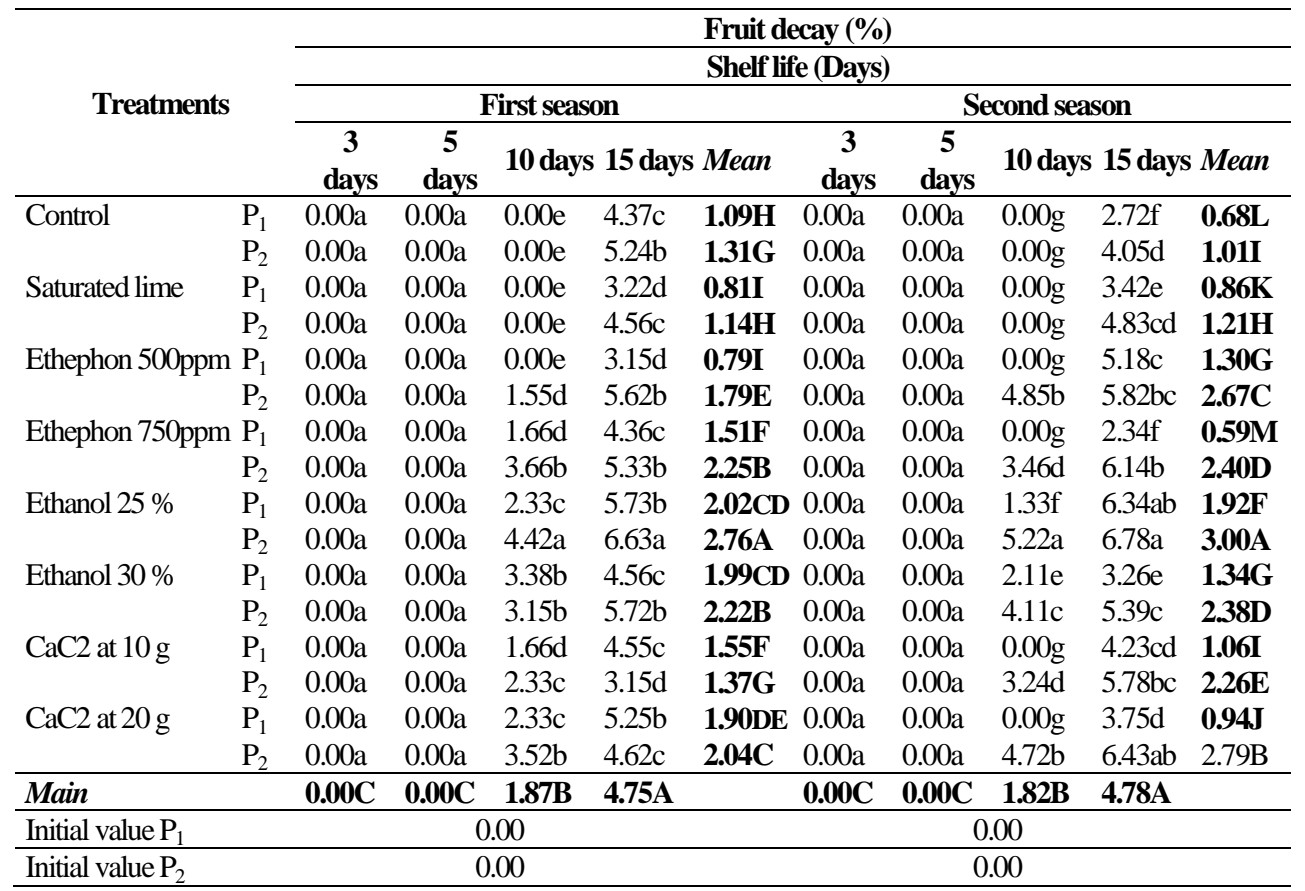

Means followed by different letter are significantly different within columns by Duncan's multiple range tests, $P \leq 0.05$.

$\mathbf{P}_{1}=$ harvesting at $50 \%$ coloration, $\mathbf{P}_{2}=$ harvesting at $75 \%$ coloration, control =Fruits dipped in water for 5 days, Saturated lime =Fruits dipped in saturated lime for 5 days, Ethephon 500 and 750 ppm =Fruits soaked in ethephon solutions for $5 \mathrm{~min}$, Ethanol 25 and $\mathbf{3 0 \%}=$ Fruits soaked in ethanol solutions for 5 $\mathrm{min}, \mathrm{CaC2}$ at 10 and 20g $=$ Fruits exposed to $\mathrm{CaC} 2$ at $10 \mathrm{~g}+40 \mathrm{ml}$ water or $20 \mathrm{~g}+40 \mathrm{ml}$ water for 1 day.

stage in both seasons.

On the other hand, fruits of both picking date and treated as control and soaked in saturated lime treatments didn't showed any fruit decay percentages after 5 and 10 days in shelf life in the first season. Moreover, fruits that picked in the first date (P1) and treated by ethephon at 750ppm, $\mathrm{CaC} 2$ at $10 \mathrm{~g}$, and $\mathrm{CaC} 2$ at $20 \mathrm{~g}$ didn't showed any fruit decay percentages after 5 and 10 days in shelf life in second season. This means that, fruits harvested at an early stage of maturity (first harvest date) suffered less. Similar results were obtained by Ramin and Tabatabaie (2003) they reported that, persimmon fruits were harvested at four stages of maturity to evaluate the practical maximum postharvest storage, the results showed fruit decay percentage was significantly increased with increasing maturity stage (harvest date) during storage. In this 
respect, Nawito (2008) concluded that, shelf life of "Hachiya" persimmon fruits greatly affected by fruit maturity where early harvest (150 days after full bloom) produced fruits with less shelf life. Late harvest (210 days after full bloom) greatly decreased fruit shelf-life as the fruits become more ripen with increased respiration rate than optimum harvested fruits (180 days after full bloom). These results are agree with the obtained of Testoni et al., (2002) and El-Badawy (2007). In this respect, decay is very important parameter due to it has a great affects the appearance and marketability of persimmons, therefore must be considered in evaluating the storage potential of persimmon fruits.

\section{Fruit firmness (Ib/inch $\left.{ }^{2}\right)$}

Data in Table 3 clear that, maturity stage and exposure to some chemical treatments were significantly affected fruit firmness of "Costata" persimmon fruits in both seasons. Fruit firmness of both maturity stages was declined after soaking in some chemical treatments as compared with control treatment where it decreased from 16.3 to 8.5 and from 16.2 to $8.3 \mathrm{Ib} /$ inch $^{2}$ after 15 days of shelf life in both seasons, respectively. "Costata" persimmon fruit of second maturity stage $\left(\mathrm{P}_{2}\right)$ that soaked in ethephon at $750 \mathrm{ppm}$ showed the lowest values of fruit firmness until 15 days of shelf life during both seasons. On contrary, the highest values of fruit firmness were recorded in fruits harvested at early maturity stage (P1) that treated with tap water (control) followed by those in saturated lime with significant differences between them in both seasons. These results are in accordance with those of El-Badawy (2007) and Abd El-Wahab et al., (2017) on "Costata" persimmon. They indicated that using ethephon, calcium carbide and ethereal for ripening persimmon fruits affected fruit firmness, in general causes a decrease in fruit firmness. Moreover, fruit firmness was higher when "Costata" persimmon fruits were harvested at the first maturity stage (50\% coloration) than that in the second one ( $75 \%$ coloration) in both seasons. Similar results were obtained by Ramin and Tabatabaie (2003), Abd El-Hafeez (2005) and Zanamwe (2014) they reported that harvesting persimmon fruit at early stage of maturity was better firmness and good shelf life than late harvest dates. Similar results were reported by Homnava et al., (1991), Edagi et al., (2009) and Kou et al., (2020). The highest fruit firmness at the end of shelf life period was recorded with control treatment followed by saturated lime; however the lowest values were noticed in ethephon at $750 \mathrm{ppm}$ treatment during the two seasons. The other treatments gave intermediate values of fruit firmness. These findings are in harmony with that of El-Zayat et al., (2004) on six varieties of persimmon, Ahmed and Sobieh (2007) and El-Badawy (2007) on "Costata" persimmon fruits. 
Table 3: Effect of removal astringency method and maturity stage on fruit firmness Ib/inch ${ }^{2}$ of "Costata" persimmon fruits during shelf life periods in 2019 and 2020 seasons

\begin{tabular}{|c|c|c|c|c|c|c|c|c|c|c|c|}
\hline \multirow{4}{*}{ Treatments } & & \multicolumn{10}{|c|}{ Firmness (Ib/inch $\left.{ }^{2}\right)$} \\
\hline & & \multicolumn{10}{|c|}{ Shelf life (Days) } \\
\hline & & \multicolumn{5}{|c|}{ First season } & \multicolumn{5}{|c|}{ Second season } \\
\hline & & $\begin{array}{c}3 \\
\text { days }\end{array}$ & $\begin{array}{c}5 \\
\text { days }\end{array}$ & 10 days & 15 days & Mean & $\begin{array}{c}3 \\
\text { days }\end{array}$ & $\begin{array}{c}5 \\
\text { days }\end{array}$ & 10 days & 15 days & s Mean \\
\hline \multirow[t]{2}{*}{ Control } & $\mathrm{P}_{1}$ & $21.7 \mathrm{a}$ & $19.9 \mathrm{a}$ & $17.2 \mathrm{a}$ & $16.4 \mathrm{a}$ & 18.8A & $19.3 \mathrm{a}$ & $18.8 \mathrm{a}$ & $17.7 \mathrm{a}$ & 17.1a & $18.2 \mathrm{~A}$ \\
\hline & $\mathrm{P}_{2}$ & $18.3 \mathrm{c}$ & $16.2 \mathrm{bc}$ & $14.3 b$ & $12.2 \mathrm{~b}$ & $15.3 B$ & $17.0 \mathrm{c}$ & $15.4 \mathrm{c}$ & $13.9 \mathrm{c}$ & $12.5 b$ & 14.7B \\
\hline \multirow[t]{2}{*}{ Saturated lime } & $\mathrm{P}_{1}$ & $19.3 \mathrm{~b}$ & $17.2 \mathrm{~b}$ & $14.5 b$ & $12.5 b$ & 15.9B & $18.1 \mathrm{~b}$ & $16.5 b$ & $14.6 \mathrm{~b}$ & $10.4 \mathrm{c}$ & 14.9B \\
\hline & $\mathrm{P}_{2}$ & $17.0 \mathrm{~d}$ & $15.9 \mathrm{bc}$ & $12.8 \mathrm{~cd}$ & $8.9 \mathrm{c}$ & $13.6 \mathrm{C}$ & $15.4 d$ & $13.5 \mathrm{e}$ & $10.6 \mathrm{e}$ & $8.6 \mathrm{e}$ & $12.0 \mathrm{D}$ \\
\hline \multirow[t]{2}{*}{ Ethephon 500ppm } & $\mathrm{P}_{1}$ & $17.2 \mathrm{~d}$ & $14.6 \mathrm{c}$ & $10.2 \mathrm{fg}$ & 7.6de & 12.4D & $17.2 \mathrm{c}$ & $15.0 \mathrm{~cd}$ & $12.6 \mathrm{~d}$ & $9.5 \mathrm{~d}$ & $13.6 \mathrm{C}$ \\
\hline & $\mathrm{P}_{2}$ & 16.4de & $13.3 \mathrm{~cd}$ & $10.7 \mathrm{ef}$ & $5.1 \mathrm{fg}$ & 11.4DE & $13.4 \mathrm{e}$ & $10.4 \mathrm{~g}$ & $10.7 \mathrm{e}$ & $6.5 \mathrm{~g}$ & $10.3 E$ \\
\hline \multirow[t]{2}{*}{ Ethephon 750ppm } & $\mathrm{P}_{1}$ & 14.2ef & $12.4 \mathrm{de}$ & $9.3 \mathrm{~g}$ & $6.4 \mathrm{e}$ & $10.6 \mathrm{E}$ & $16.6 \mathrm{~cd}$ & $13.3 \mathrm{e}$ & $11.2 \mathrm{de}$ & $6.9 \mathrm{fg}$ & 12.0D \\
\hline & $\mathrm{P}_{2}$ & $13.6 \mathrm{f}$ & $11.3 \mathrm{e}$ & $9.2 \mathrm{~g}$ & $4.7 \mathrm{~g}$ & 9.7F & 14.1de & $8.5 \mathrm{i}$ & $5.4 \mathrm{~h}$ & $3.5 \mathrm{i}$ & $7.9 \mathrm{H}$ \\
\hline \multirow[t]{2}{*}{ Ethanol $25 \%$} & $\mathrm{P}_{1}$ & $17.5 \mathrm{~d}$ & $15.2 \mathrm{bc}$ & $13.4 \mathrm{bc}$ & $8.5 \mathrm{~cd}$ & $13.7 \mathrm{C}$ & $17.5 \mathrm{c}$ & $16.5 b$ & $13.5 \mathrm{c}$ & $8.5 \mathrm{e}$ & $14.0 \mathrm{C}$ \\
\hline & $\mathrm{P}_{2}$ & 14.6ef & $12.4 \mathrm{de}$ & $10.4 f g$ & $8.5 \mathrm{~cd}$ & 11.5DE & $15.0 \mathrm{~d}$ & $10.5 \mathrm{~g}$ & $8.7 \mathrm{f}$ & $7.5 \mathrm{f}$ & $10.4 \mathrm{E}$ \\
\hline \multirow[t]{2}{*}{ Ethanol $30 \%$} & $\mathrm{P}_{1}$ & $15.7 \mathrm{de}$ & $13.5 \mathrm{~cd}$ & 11.9de & 7.2de & 12.1DE & $17.4 \mathrm{c}$ & $15.7 \mathrm{c}$ & $13.7 \mathrm{c}$ & $9.4 \mathrm{~d}$ & 14.0C \\
\hline & $\mathrm{P}_{2}$ & 15.9de & 12.6de & $10.5 \mathrm{fg}$ & 7.2de & 11.6DE & $14.9 \mathrm{~d}$ & $9.2 \mathrm{~h}$ & $7.6 \mathrm{j}$ & $5.8 \mathrm{~h}$ & 9.4F \\
\hline \multirow[t]{2}{*}{$\mathrm{CaC} 2$ at $10 \mathrm{~g}$} & $\mathrm{P}_{1}$ & 16.4de & $14.2 \mathrm{c}$ & $13.5 b c$ & 7.5de & 12.9D & $17.0 \mathrm{c}$ & $14.8 \mathrm{~cd}$ & $12.9 \mathrm{~d}$ & $9.3 \mathrm{~d}$ & 13.5C \\
\hline & $\mathrm{P}_{2}$ & 15.2de & $13.2 \mathrm{~cd}$ & 10.9ef & $8.9 \mathrm{c}$ & 12.0DE & $15.2 \mathrm{~d}$ & $12.5 \mathrm{f}$ & $7.3 \mathrm{j}$ & $6.8 \mathrm{fg}$ & $10.5 \mathrm{E}$ \\
\hline \multirow[t]{2}{*}{$\mathrm{CaC} 2$ at $20 \mathrm{~g}$} & $\mathrm{P}_{1}$ & 14.3ef & $12.5 \mathrm{de}$ & $9.5 \mathrm{lfg}$ & $6.3 \mathrm{ef}$ & $10.6 \mathrm{E}$ & $16.3 \mathrm{~cd}$ & $14.3 \mathrm{~d}$ & $11.3 \mathrm{de}$ & $7.0 \mathrm{fg}$ & $12.3 D$ \\
\hline & $\mathrm{P}_{2}$ & 14.0ef & $12.8 \mathrm{de}$ & $10.2 \mathrm{fg}$ & $8.1 \mathrm{~cd}$ & 11.3DE & $14.2 \mathrm{~d}$ & $10.7 \mathrm{~g}$ & $5.7 \mathrm{~h}$ & $3.3 \mathrm{i}$ & 8.5G \\
\hline \multicolumn{2}{|l|}{ Mean } & $16.3 \mathrm{~A}$ & $14.2 \mathrm{~B}$ & $11.8 \mathrm{C}$ & 8.5D & & $16.2 \mathrm{~A}$ & 13.5B & 11.1C & 8.3D & \\
\hline \multicolumn{2}{|l|}{ Initial value $\mathrm{P}_{1}$} & \multicolumn{5}{|c|}{21.4} & \multicolumn{4}{|c|}{19.5} & \\
\hline \multicolumn{2}{|l|}{ Initial value $\mathrm{P}_{2}$} & \multicolumn{4}{|c|}{18.2} & \multicolumn{5}{|c|}{17.2} & \\
\hline \multicolumn{12}{|c|}{$\begin{array}{l}\text { Means followed by different letter are significantly different within columns by Duncan's multiple range } \\
\text { tests, } P \leq 0.05 \text {. }\end{array}$} \\
\hline \multicolumn{12}{|c|}{$\begin{array}{l}\mathbf{P}_{1}=\text { harvesting at } 50 \% \text { coloration, } \mathbf{P}_{2}=\text { harvesting at } 75 \% \text { coloration, control }=\text { Fruits dipped in water for } 5 \\
\text { days, Saturated lime =Fruits dipped in saturated lime for } 5 \text { days, Ethephon } \mathbf{5 0 0} \text { and } \mathbf{7 5 0} \text { ppm =Fruits } \\
\text { soaked in ethephon solutions for } 5 \mathrm{~min} \text {, Ethanol } \mathbf{2 5} \text { and } \mathbf{3 0 \%}=\text { Fruits soaked in ethanol solutions for } 5 \\
\text { min, } \mathbf{C a C} 2 \text { at } \mathbf{1 0} \text { and } 20 \mathrm{~g}=\text { Fruits exposed to } \mathrm{CaC} 2 \text { at } 10 \mathrm{~g}+40 \mathrm{ml} \text { water or } 20 \mathrm{~g}+40 \mathrm{ml} \text { water for } 1 \text { day. }\end{array}$} \\
\hline
\end{tabular}

\section{Total tannins content:}

The results in Table 4 indicated that, postharvest dipping of persimmon fruits in some ripening chemical treatments were effective in reducing total tannins content during shelf life period compared to control treatment in both seasons. Total tannins were gradually decreased with increasing ripening duration from 1.07 to 0.53 and from 1.04 to $0.56 \mathrm{mg} / 100 \mathrm{ml}$ of fruit juice after 15 days of shelf life in both seasons, respectively. Moreover, combination (control $+\mathrm{P}_{1}$ ) treatment recoded the highest significant value of total tannins as compared with the other treatments in both seasons. On the other hand, the lowest value of total tannins was associated with fruits that harvested in second picking date $\left(\mathrm{P}_{2}\right)$ and soaked in ethephon at $750 \mathrm{ppm}, \mathrm{CaC} 2$ at $20 \mathrm{~g}$ after 5 and 10 days of shelf life in first seasons, however in the second season it was associated with ethephon at 500 and $750 \mathrm{ppm}$ as well as $\mathrm{CaC} 2$ at 10 and $20 \mathrm{~g}$, 
Table 4: Effect of removal astringency method and maturity stage on total tannins content of "Costata" persimmon fruits during shelf life in 2019 and 2020 seasons

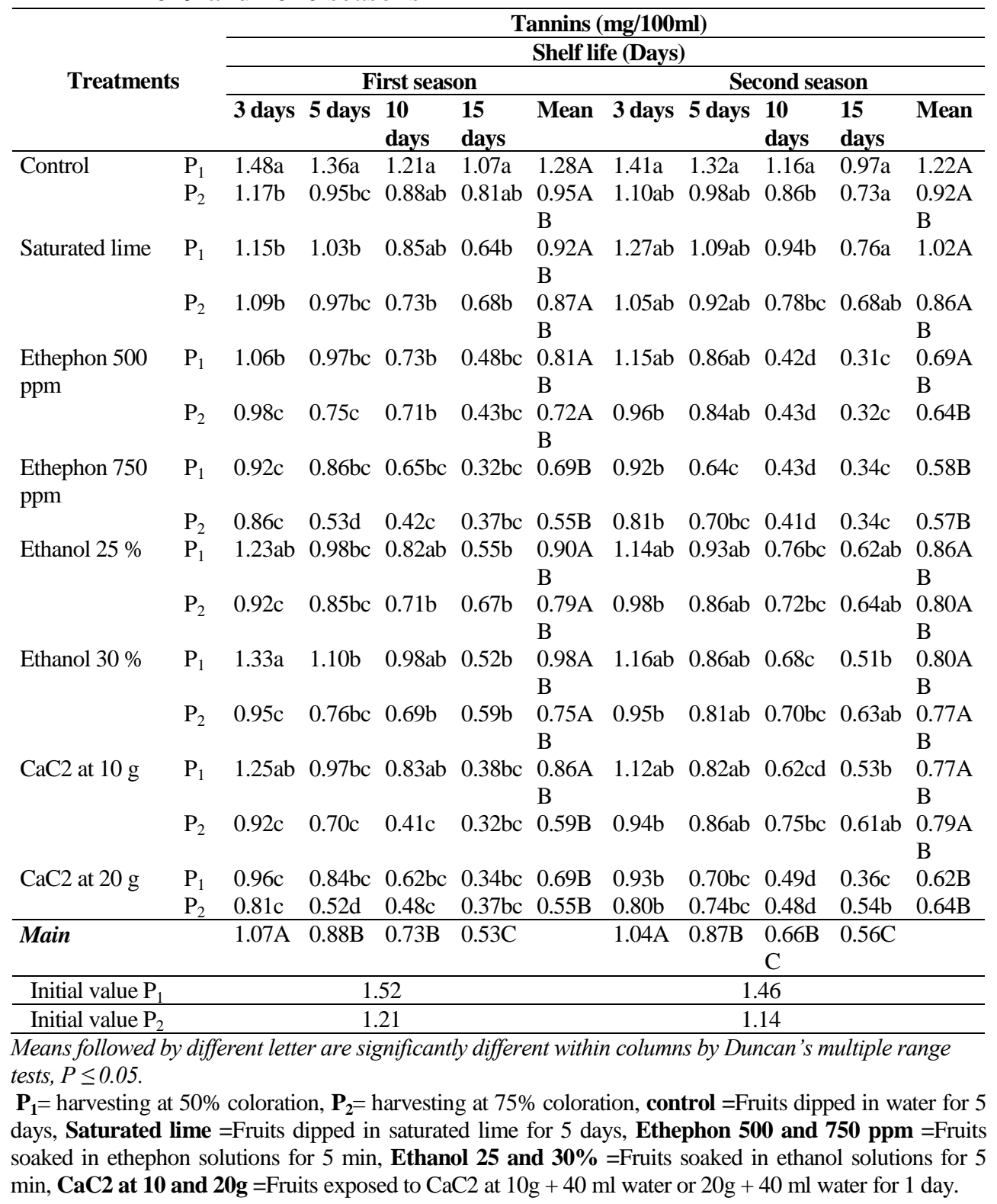

regardless picking dates. These results are in agreement with El-Badawy (2007) and Abd El-Wahab et al., (2017) on "Costata" persimmon fruits. 
Moreover, Kim et al., (2004) and Borras (2015) they reported that, ethephon treatment greatly accelerated the coagulation and disappearance of astringency from persimmon fruits. Also, Del Bubba et al., (2009) showed that treatments of ethylene and $\mathrm{CO}_{2}$ had a significant influence on soluble tannin concentrations and the corresponding antiradical activity. Based on the usually accepted threshold level for human de-astringency detection, the 3-day treatment with ethylene was not sufficient for making the persimmons edible, while the application of $\mathrm{CO}_{2}$ for $24 \mathrm{~h}$ reduced the soluble tannins to well below the above-mentioned level. In this respect, ethylene treatment from different sources i.e. Ethephon, ethanol, ethylene generating kits at different concentrations (100-5000 ppm) for different periods on the relationship between the decrease in tannin concentration and loss of astringency of persimmon fruits (Rouhani et al., 1975, Kamal and Rabeh 1989 and Zanamwe, 2014).

\section{Carotenoids content:}

It is obvious from Table 5 that, removal astringency methods used were effective in enhancing fruit carotenoids content in both maturity stages of fruits. Carotenoids content of fruit was gradually increased with the incidence of maturation stage from 1.89 to 2.26 and from 1.73 to $2.26 \mathrm{mg} / 100 \mathrm{ml}$ after 15 days of shelf life in seasons, respectively. Moreover, the results indicated that chemical treatments caused a progressive increment in fruit carotenoids content as compared with control in both seasons. Fruits that harvested in the second maturity stage $\left(\mathrm{P}_{2}\right)$ and soaked in ethephon at 500 and $750 \mathrm{ppm}$, Ethanol 25 and $30 \%$, and exposed to calcium carbide at 10 and $20 \mathrm{~g}$ showed the highest values of fruit carotenoids content after 5, 10 and 15 days in shelf life without significant differences between them in first seasons. Whoever, the highest values of fruit carotenoids content observed by fruits of $2^{\text {nd }}$ maturity stage $\left(\mathrm{P}_{2}\right)$ which soaked in ethephon at $750 \mathrm{ppm}$ and calcium carbide at $20 \mathrm{~g}$ in most cases during second season. On the other hand, the lowest values in this concern were recorded in fruits of $\mathrm{P}_{1}$ that dipped in tap water (control) and saturated lime in both seasons. The enhancement of carotenoids development due to calcium carbide and ethephon treatments were explained by El-Badawy (2007) and Bordiga et al. (2019) they summarized that, fruit carotenoids content was in parallel with the ripening duration, this may be due to the fact that the synthesis of carotenoids is accompanied by changes in the ultra-structure of plastids. Moreover, the role of ethephon in enhancing fruit carotenoids may be due to the fact that ethephon accelerates the previously mentioned changes which lead to carotenoids synthesis (Kamal and Rabeh, 1989). The enhancement and positive effect of ripening treatments on persimmon fruit 
Table 5: Effect of removal astringency method and maturity stage on carotenoids content of "Costata" persimmon fruits during shelf life period in 2019 and 2020 seasons

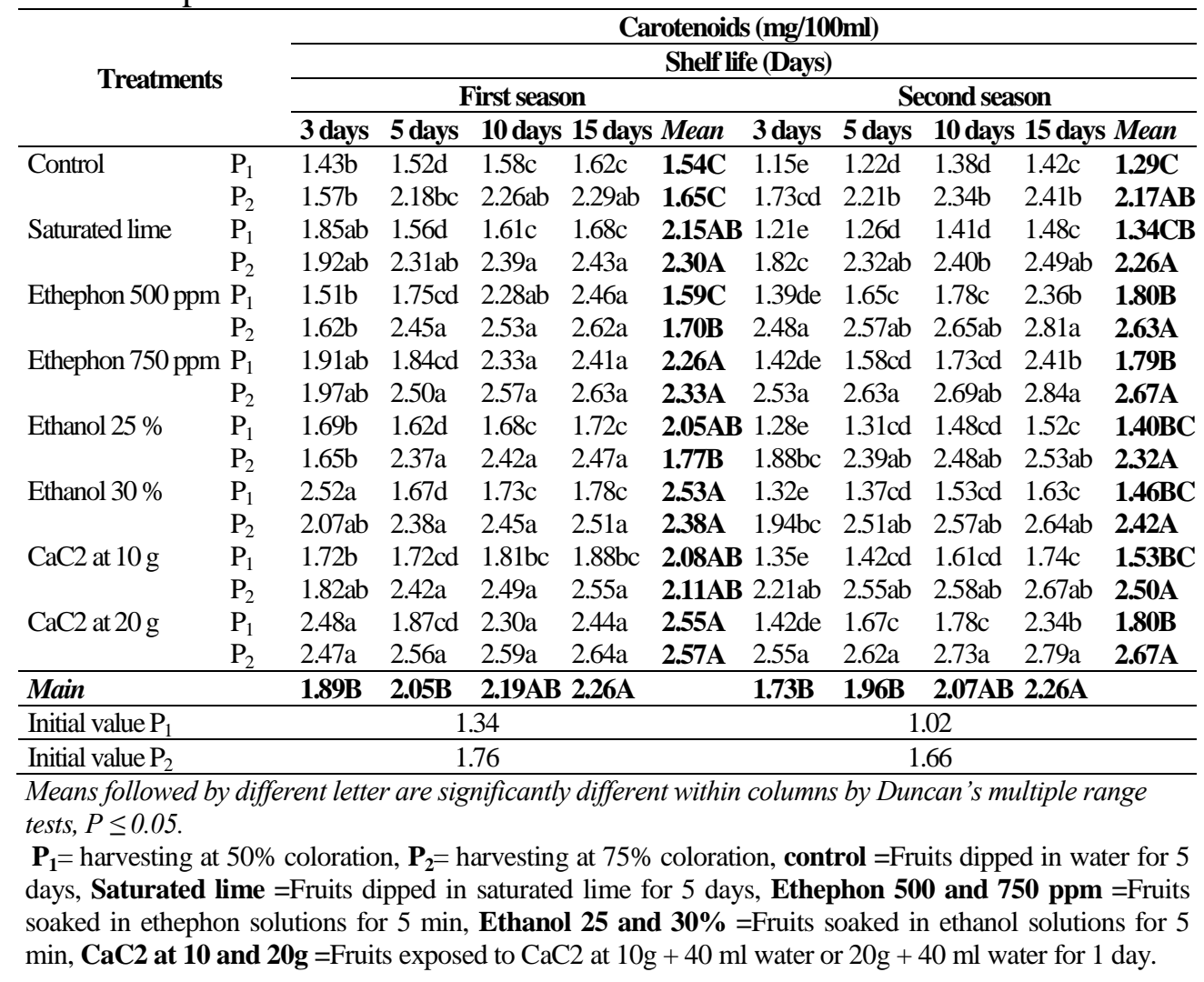

color is in agreement with Testoni (2002), Luo (2006) and El-Naggar (2018).

Soluble solids content (SSC \%):

Data in Table 6 show the results of soluble solid content (SSC \%) of Costata persimmon fruits at two maturity stages treated by some chemical applications. Soluble solid content (SSC \%) increased gradually as shelf life time progressed where it increased from 13.7 to 18.5 and from 13.1 to $18.5 \%$ after 15 days of shelf life in both seasons, respectively. The values of SSC \% of control (fruit dipped in tap water) in both maturity stages were lower than those dipped in different chemical treatments in both seasons. During shelf life period, the highest SSC \% was recorded in fruits of $2^{\text {nd }}$ maturity stage $\left(\mathrm{P}_{2}\right)$ which soaked in ethephon at 500 and $750 \mathrm{ppm}$ as well as exposed to $\mathrm{CaC} 2$ at 10 and $20 \mathrm{~g}$ without significant deference among them in both seasons, while the lowest value was found in control treatments of $1^{\text {st }}$ maturity stage $\left(\mathrm{P}_{1}\right)$ in 
Table 6: Effect of removal astringency method and maturity stage on soluble solids content (SSC \%) of "Costata" persimmon fruits during shelf life period 2019 and 2020 seasons

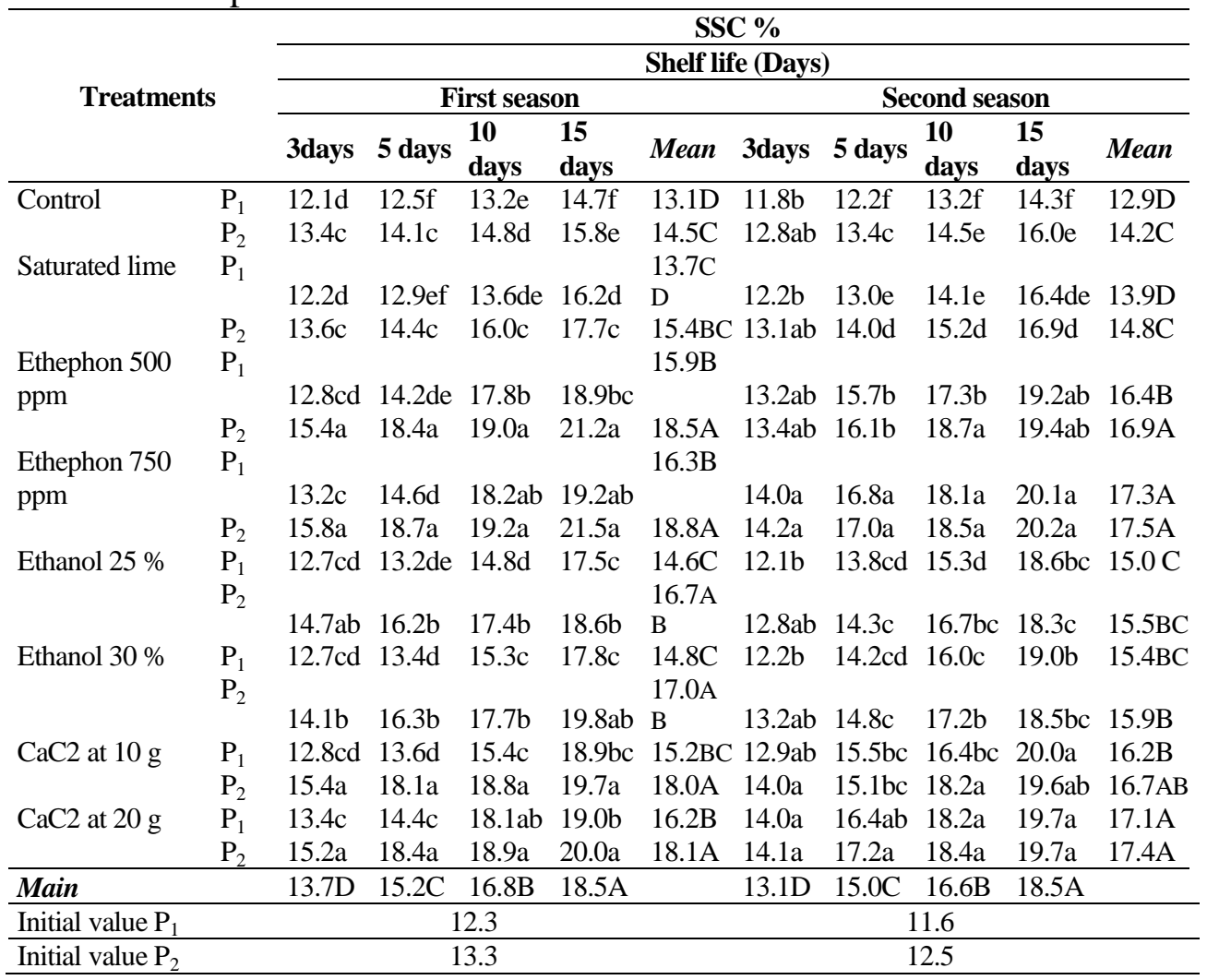

Means followed by different letter are significantly different within columns by Duncan's multiple range tests, $P \leq 0.05$.

$\mathbf{P}_{1}=$ harvesting at $50 \%$ coloration, $\mathbf{P}_{2}=$ harvesting at $75 \%$ coloration, control $=$ Fruits dipped in water for 5 days, Saturated lime =Fruits dipped in saturated lime for 5 days, Ethephon $\mathbf{5 0 0}$ and $\mathbf{7 5 0}$ ppm =Fruits soaked in ethephon solutions for $5 \mathrm{~min}$, Ethanol 25 and 30\% =Fruits soaked in ethanol solutions for 5 $\min , \mathbf{C a C 2}$ at 10 and 20g $=$ Fruits exposed to $\mathrm{CaC} 2$ at $10 \mathrm{~g}+40 \mathrm{ml}$ water or $20 \mathrm{~g}+40 \mathrm{ml}$ water for 1 day.

both seasons. Similar results were obtained by Rouhani et al. (1975) and Shiesh et al. (2000). In this respect, El-Badawy (2007) demonstrated that ethephon treatment had a positive effect on soluble solids content of Costata persimmon fruits. Thus, using ethephon at $750 \mathrm{ppm}$ or $\mathrm{CaC} 2$ maintain high level of soluble solids content (SSC \%) at different period of shelf life compared to control. The increase in total soluble solids of fruits resulting from treatments may be related to the hydrolytic activities in starch, the increased activity of enzymes responsible for the hydrolysis of starch to soluble sugars, and the conversion of starch to sugar, which indicates that the fruits are at the ripening process. This explanation agrees with those results obtained by Zanamwe, (2014). 


\section{Titratable acidity}

Data presented in Table 7 show the changes in titratable acidity of "Costata" persimmon fruits harvested at two maturity stages and exposed to some chemical treatments for removal astringency substances during 2019 and 2020 seasons. All treatments recorded low levels of titratable acidity of persimmon fruits during shelf life period compared to control treatment in both seasons.

Table 7: Effect of removal astringency method and maturity stage on acidity \% of "Costata" persimmon fruits during shelf life period in 2019 and 2020 seasons

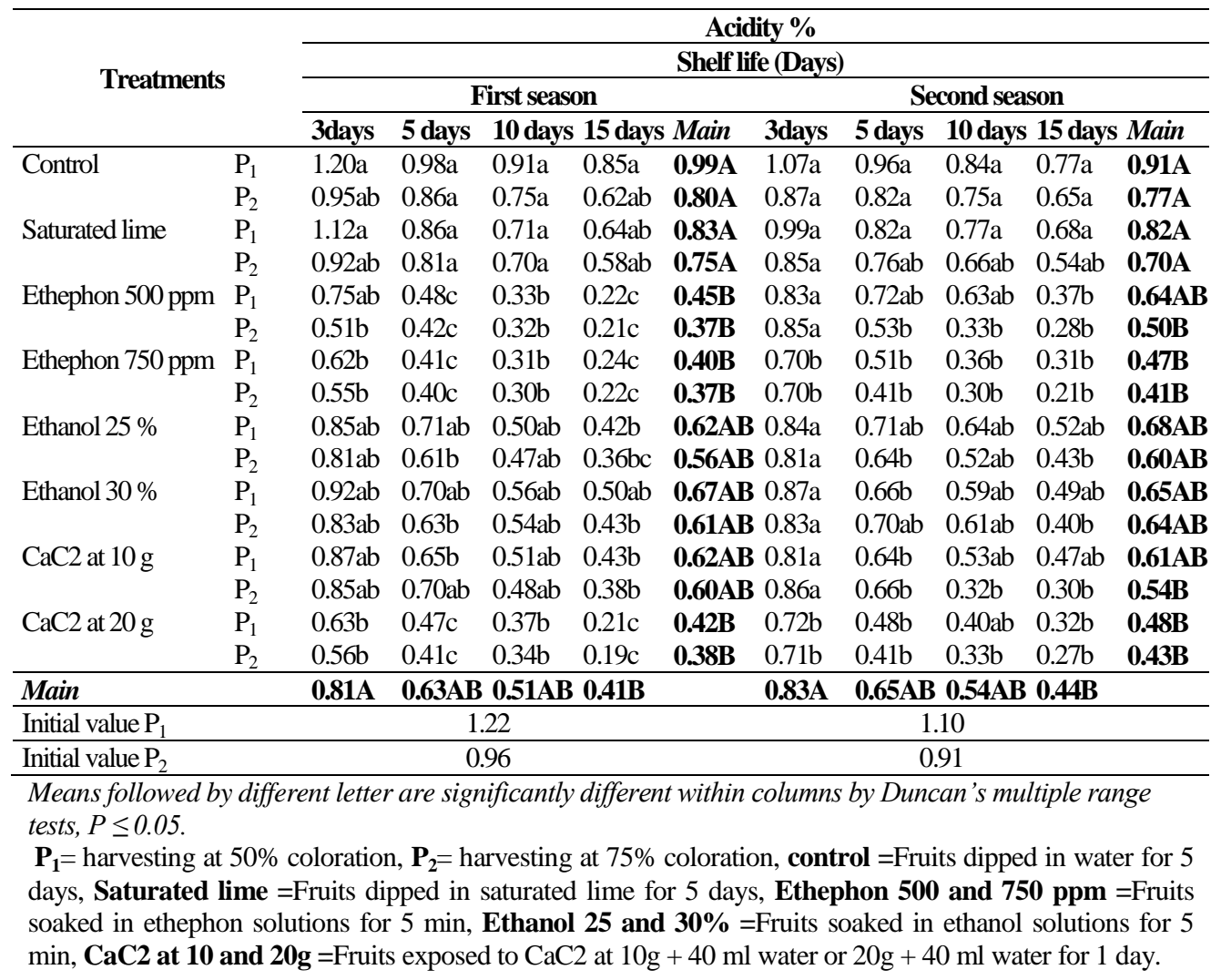

In addition titratable acidity values were gradually decreased with incidence of shelf life period since; it decreased from 0.81 to 0.41 and from 0.83 to $0.44 \%$ after 15 days of shelf life in both seasons, respectively. The higher values of titratable acidity were observed in control saturated lime treatments regardless harvesting date in most cases after 5, 10 and 15days of shelf life in both seasons. Whereas, the lowest values of titratable acidity were associated with ethephon at 500 and $750 \mathrm{ppm}$, as well as, calcium carbide at 20g in both 
maturity stages used in both seasons. The differences among ethephon at 500 and $750 \mathrm{ppm}$ and calcium carbide at $20 \mathrm{~g}$ were not significant in both seasons. These results were similar with those reported by Rouhani et al. (1975), Kamal and Rabeh (1989) and El-Badawy (2007). In this respect, Testoni (2002) reported that persimmon fruits dipped in some growth regulators recorded low level of titratable acidity during repining and shelf life period. As the ripening of the fruits develops, a reduction in titratable acidity is observed. The decrease in acid content is caused by the use of acids in the fruit as a source of energy and the conversion of organic acids to form sugar (Borras, 2015).

\section{SSC/acid ratio:}

Data in Table 8 show the changes in SSC/acid ratio of "Costata" persimmon fruits harvested at two dates and exposed to some chemical treatments for removal astringency substances during 2019 and 2020 seasons.

Table 8: Effect of removal astringency method and maturity stage on SSC/acid ratio of "Costata" persimmon fruits during shelf life period in 2019 and 2020 seasons

\begin{tabular}{|c|c|c|c|c|c|c|c|c|c|c|c|}
\hline \multirow{4}{*}{ Treatments } & & \multicolumn{10}{|c|}{ SSC/acid ratio } \\
\hline & & \multicolumn{10}{|c|}{ Shelf life (Days) } \\
\hline & & \multicolumn{5}{|c|}{ First season } & \multicolumn{5}{|c|}{ Second season } \\
\hline & & 3 days & 5 days & 10 days & 15 days & Mean & 3 days & 5 days & 10 days & 15 days & Mean \\
\hline \multirow[t]{2}{*}{ Control } & $\mathrm{P}_{1}$ & $10.1 \mathrm{e}$ & $12.8 \mathrm{j}$ & 14.51 & $17.3 n$ & 13.7J & $11.0 \mathrm{e}$ & $12.7 \mathrm{li}$ & 15.71 & $18.6 \mathrm{~m}$ & $14.5 H$ \\
\hline & $\mathrm{P}_{2}$ & 14.1cd & $16.4 \mathrm{i}$ & $19.7 \mathrm{k}$ & $25.5 \mathrm{~m}$ & 18.9HI & $14.7 b c$ & $16.3 \mathrm{~h}$ & $19.3 \mathrm{i}$ & 24.61 & $18.8 F$ \\
\hline \multirow[t]{2}{*}{ Saturated lime } & $\mathrm{P}_{1}$ & $10.9 \mathrm{e}$ & 15.0li & $19.2 \mathrm{k}$ & $25.3 \mathrm{~m}$ & 17.6I & $12.3 \mathrm{~d}$ & $15.9 \mathrm{~h}$ & $18.3 \mathrm{i}$ & 24.11 & $17.7 \mathrm{G}$ \\
\hline & $\mathrm{P}_{2}$ & $14.8 \mathrm{~cd}$ & 17.8hi & $22.9 j$ & 30.51 & $21.5 \mathrm{H}$ & $15.4 b$ & $18.4 \mathrm{j}$ & 23.0h & $31.3 \mathrm{k}$ & 22.0E \\
\hline \multirow[t]{2}{*}{ Ethephon 500 ppm } & $\mathrm{P}_{1}$ & $17.1 \mathrm{c}$ & $29.6 \mathrm{e}$ & $53.9 \mathrm{c}$ & $85.9 \mathrm{e}$ & 46.6C & $15.9 b$ & $21.8 \mathrm{f}$ & $27.5 \mathrm{~g}$ & $51.9 f$ & 29.3D \\
\hline & $\mathrm{P}_{2}$ & $30.2 \mathrm{a}$ & $43.8 \mathrm{c}$ & $59.4 b$ & $101.0 b$ & 58.6A & $15.8 b$ & $30.4 d$ & $56.7 \mathrm{~b}$ & $69.3 c$ & 43.0C \\
\hline \multirow[t]{2}{*}{ Ethephon 750 ppm } & $\mathrm{P}_{1}$ & $21.3 \mathrm{~b}$ & $35.6 \mathrm{~d}$ & $58.7 \mathrm{~b}$ & $80.0 f$ & 48.9B & $20.0 \mathrm{a}$ & $32.9 \mathrm{c}$ & $50.3 d$ & $64.8 \mathrm{~d}$ & 42.0C \\
\hline & $\mathrm{P}_{2}$ & $28.7 \mathrm{ab}$ & $46.8 \mathrm{a}$ & $64.0 \mathrm{a}$ & $97.7 \mathrm{c}$ & 59.3A & $20.3 a$ & $41.5 \mathrm{a}$ & $61.7 \mathrm{a}$ & $96.2 \mathrm{a}$ & 54.9A \\
\hline \multirow[t]{2}{*}{ Ethanol $25 \%$} & $\mathrm{P}_{1}$ & $14.9 \mathrm{~cd}$ & $18.6 \mathrm{~h}$ & 29.6h & $41.7 \mathrm{j}$ & $26.2 \mathrm{~F}$ & $14.4 \mathrm{c}$ & $19.4 j$ & $23.9 \mathrm{j}$ & $35.8 \mathrm{j}$ & 23.4DE \\
\hline & $\mathrm{P}_{2}$ & $18.2 \mathrm{c}$ & $26.6 \mathrm{f}$ & $37.0 \mathrm{f}$ & $51.7 \mathrm{~g}$ & 33.4D & $15.8 \mathrm{~b}$ & $22.3 f$ & $32.1 \mathrm{f}$ & $42.6 \mathrm{~h}$ & 28.2D \\
\hline \multirow[t]{2}{*}{ Ethanol $30 \%$} & $\mathrm{P}_{1}$ & $13.8 \mathrm{~d}$ & $19.1 \mathrm{~h}$ & $27.3 \mathrm{i}$ & $35.0 \mathrm{k}$ & $24.0 G$ & $14.0 \mathrm{c}$ & $21.5 f$ & $27.1 \mathrm{~g}$ & $38.8 \mathrm{i}$ & 25.4DE \\
\hline & $\mathrm{P}_{2}$ & $16.9 \mathrm{c}$ & $25.9 f$ & $32.7 \mathrm{~g}$ & $46.1 \mathrm{~h}$ & $30.4 \mathrm{E}$ & $15.9 \mathrm{~b}$ & $21.1 f$ & $28.2 \mathrm{~g}$ & $46.3 \mathrm{~g}$ & 27.9D \\
\hline \multirow[t]{2}{*}{$\mathrm{CaC} 2$ at $10 \mathrm{~g}$} & $\mathrm{P}_{1}$ & $14.7 \mathrm{~cd}$ & $20.9 \mathrm{~g}$ & $30.2 \mathrm{~h}$ & $44.0 \mathrm{i}$ & $27.5 \mathrm{~F}$ & $15.9 b$ & $24.2 \mathrm{e}$ & $30.9 f$ & $42.6 \mathrm{~h}$ & 28.4D \\
\hline & $\mathrm{P}_{2}$ & $18.1 \mathrm{c}$ & $25.9 f$ & $39.2 \mathrm{e}$ & $51.8 \mathrm{~g}$ & 33.8D & $16.9 \mathrm{~b}$ & $22.9 f$ & $56.9 b$ & $65.3 \mathrm{~d}$ & 40.3CD \\
\hline \multirow[t]{2}{*}{$\mathrm{CaC} 2$ at $20 \mathrm{~g}$} & $\mathrm{P}_{1}$ & $21.3 b$ & $30.6 \mathrm{e}$ & $48.9 \mathrm{~d}$ & $90.5 d$ & 47.8B & $19.4 \mathrm{a}$ & $34.2 b$ & $45.5 \mathrm{e}$ & $61.6 \mathrm{e}$ & $40.2 \mathrm{CD}$ \\
\hline & $\mathrm{P}_{2}$ & $27.1 \mathrm{ab}$ & $44.9 \mathrm{~b}$ & $55.6 \mathrm{c}$ & $105.3 \mathrm{a}$ & 58.2A & $19.9 \mathrm{a}$ & $42.0 \mathrm{a}$ & $55.8 \mathrm{c}$ & $73.0 \mathrm{~b}$ & 47.6B \\
\hline Main & & 18.3D & $26.9 \mathrm{C}$ & 38.3B & 58.1A & & 16.1D & $24.9 \mathrm{C}$ & 35.8B & 49.2A & \\
\hline Initial value $\mathrm{P}_{1}$ & & \multicolumn{5}{|c|}{10.08} & \multicolumn{5}{|c|}{13.85} \\
\hline Initial value $\mathrm{P}_{2}$ & & \multicolumn{5}{|c|}{10.55} & \multicolumn{5}{|c|}{13.74} \\
\hline
\end{tabular}

Means followed by different letter are significantly different within columns by Duncan's multiple range tests, $P \leq 0.05$

$\mathbf{P}_{1}=$ harvesting at $50 \%$ coloration, $\mathbf{P}_{2}=$ harvesting at $75 \%$ coloration, control $=$ Fruits dipped in water for 5 days, Saturated lime $=$ Fruits dipped in saturated lime for 5 days, Ethephon 500 and 750 ppm =Fruits soaked in ethephon solutions for $5 \mathrm{~min}$, Ethanol 25 and $\mathbf{3 0 \%}=$ Fruits soaked in ethanol solutions for 5 $\min , \mathbf{C a C 2}$ at 10 and 20g =Fruits exposed to $\mathrm{CaC} 2$ at $10 \mathrm{~g}+40 \mathrm{ml}$ water or $20 \mathrm{~g}+40 \mathrm{ml}$ water for 1 day. 
All treatments recorded high levels of SSC/acid ratio in persimmon fruits during shelf life period compared to control treatment in both seasons. In addition SSC/acid ratio values were gradually increased with increasing shelf life period from 18.3 to 58.2 and from 16.1 to 49.2 after 15 days of shelf life in both seasons, respectively. Moreover, the higher values of SSC/acid ratio were observed in fruits of second picking date $\left(\mathrm{P}_{2}\right)$ which soaked in ethephon at 750 ppm after 5 and 10 days in shelf life in the first season and after 3, 5, 10 and 15 days in the second one. In contrary that, the lowest values of SSC/acid ratio were observed in fruits of $1^{\text {st }}$ maturity stage that dipped in tap water (control) followed by fruits dipped in saturated lime in both seasons. These results were similar with those reported by Testoni (2002) and Borras (2015).

\section{Ascorbic acid:}

Data presented in Table 9 show that, ascorbic acid content in "Costata" persimmon fruits were gradually decreased as shelf life period prolonged,

Table 9: Effect of removal astringency method and maturity stage on ascorbic acid content of "Costata" persimmon fruits during shelf life period in 2019 and 2020 seasons

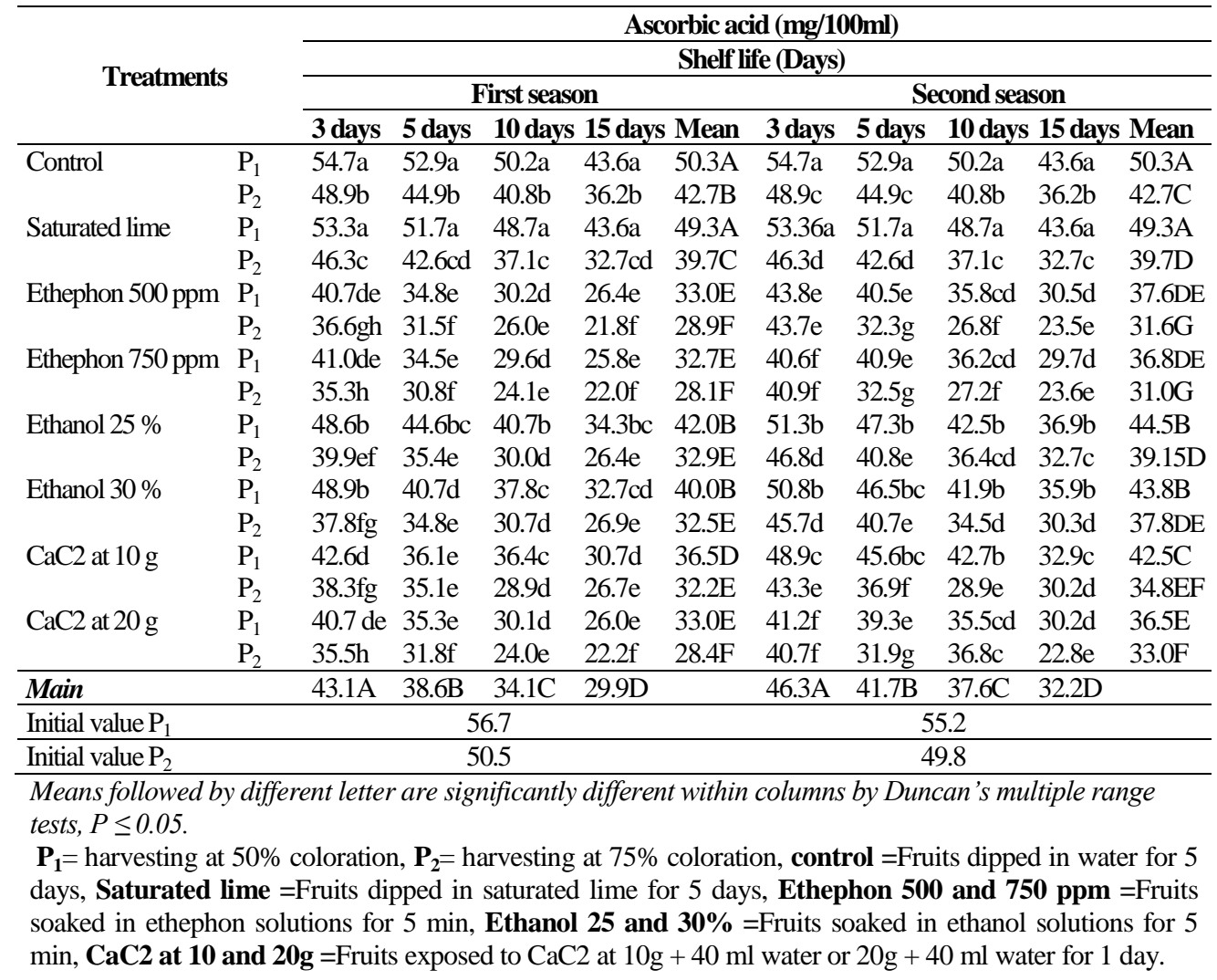


where it decreased from 43.1 to 29.9 and from 46.3 to 32.2 after 15 days of shelf life in both seasons, respectively. Moreover, fruits dipped in different chemical treatments had significantly lower ascorbic acid content than that dipped on tap water (control) in both seasons.

The highest ascorbic acid content was showed by fruits harvested at $2^{\text {nd }}$ date $\left(\mathrm{P}_{2}\right)$ which dipped in tap water (control) and fruits soaked in saturated lime without significant difference between them in both seasons., whereas, fruits of $\mathrm{P}_{2}$ which treated by ethephon at 500 and $750 \mathrm{ppm}$ as well as calcium carbide $20 \mathrm{~g}$ produced the lowest values of ascorbic acid in most cases in both seasons. So, it can be concluded that ethephon and calcium carbide at $20 \mathrm{~g}$ application led to loss fruits their content of ascorbic acid during repining and shelf life period. The same trend was also observed in the previous study by Gomez and Lajolo (2008) they concluded that reduction in fruit ascorbic acid content during ripening could be attributed to the increase in ascorbate oxidase activity and ethephon treatment increases such oxidation process.

\section{CONCLUSION}

In light of this study it can be concluded that, "Costata" persimmon fruits harvested at $75 \%$ coloration soaked in ethephon at $750 \mathrm{ppm}$ for $5 \mathrm{~min}$ as well as fruits that exposed to gases resulted from mixing of calcium carbide at $20 \mathrm{~g}$ with $40 \mathrm{ml}$ water in a small closed chamber $\left(8 \mathrm{~m}^{2}\right)$ for $24 \mathrm{~h}$ are found to be more effective artificial astringency removal methods in maintaining firmness, titratable acidity, ascorbic acid, soluble solids content and SSC/acid ratio of Costata persimmon fruits for 15 days in shelf life and removes the astringency. So it could be recommended to use one of the above mentioned treatments for removing the astringency of Costata persimmon fruits with maintains the quality during shelf life.

\section{REFERENCES}

A.O.A.C. (1990). Association Of Official Analytical Chemists. Official Methods of Analysis. 15th Ed. Washington D.C., USA.

Abd El-Hafeez, A.A. (2005). The effect of harvesting date and cold storage on quality of "Costata" persimmon fruits. Minufiya J. Agric. Res., 30(5):14771496.

Abd El-Wahab, S.M.; H.M. Kamel; A.A. Abd El-Hafeez and M.T. Osman (2017). Comparison of different ripening methods for removing astringency in "Costata" persimmon fruits. Middle East Journal of Agriculture Research, 6(2): 569 - 583. 
Ahmed, D.M. and M.E. Sobieh (2007). Removing astringency of Costata persimmon fruits by carbon dioxide and nitrogen enriched atmosphere. American Eurasian J. Agric. \& Environ. Sci., 2(6): 731 - 740.

Bordiga, M.; F. Travaglia; D. Giuffrida; D. Mangraviti; F. Rigano; L. Mondello and J.D. Caisson, (2019). Characterization of peel and pulp proanthocyanidins and carotenoids during ripening in persimmon Kaki cv. cultivated in Italy. Food Research International, 120: 800 - 809.

Borras, P.N. (2015). Harvest and postharvest quality of persimmon fruit: physicochemical and nutritional aspect. Ph.D. Thesis, Food Technology Department, Nstituto Valenciano de Investigaciones Agrarias (IVIA), Universitat Politecnica De Valencia, ALÈNCIA, Spain.

Das, P.R. and J.B. Eun (2020). Removal of astringency in persimmon fruits (Diospyros kaki) subjected to different freezing temperature treatments. Journal of Food Science and Technology, https://doi.org/10.1007/s13197-020-04818-3

Del Bubba, M.; E. Giordani, L. Pippucci, A. Cincinelli, L. Checchini and P. Galvan, (2009). Changes in tannins, ascorbic acid and sugar content in astringent persimmons during on-tree growth and ripening and in response to different postharvest treatments. Journal of Food Composition and Analysis, 22(7-8): 668 - 677.

Duncan, D.B. (1955). Multiple ranges and multiple F. test. Biometries.11: 1- 42.

Ebert, G. and J. Gross, (1985). Carotenoid changes in the peel of ripening persimmon (Diospyros kaki) cv. triumph. Phytochemistry, 24 (1): 29-32

Edagi, F.K.; I. Sestari, F.A.M. Terra, D.G. Chiou, R.A. Kluge and L.R. Antoniolli (2009). Effect of ripening stage on astringency removal of 'Rama Forte' persimmon. Acta Hort., 833: 269 - 274.

El-Badawy, H. E. (2007). Trials to improve marketing characteristics and prolonging storage life of persimmon and mango fruits. Ph.D. Thesis, Hort. Dept., Fac. Agric., Benha University, Egypt.

EL-Kady, M.I.; B.N. Samra and R.A. Badawy (2008). Astringency removal and ripening process of persimmons treated with ethephon and ethanol. $J$. Agric. Sci. Mansoura Univ., 33(5): 3545 - 3553.

EL-Naggar, N.I. (2018). Delay ripening changes and extending the storage period of Costata persimmon fruits by 1-MCP application. Middle East Journal of Applied Sciences, 8(4): 1290 - 1300.

El-Zayat, H.E.; A.A. Abdel-Hafeez and M.M. Yehia (2004). Evaluation of some ripens methods for persimmon fruits. Journal of Agriculture Science, Mansoura University, 29(2): 761 - 773. 
Ennab, H.A.; M.A. Soliman and G.B. Mikhael (2018). Replacing nitrogen fertilization by using organic and biofertilizers on Costata persimmon trees. J. Product. \& Dev., 23(1): $39-59$.

Gautam, A.; A.K Dhiman; S. Attri and D. Kathuria (2020). Nutritional and functional characteristics of ripe persimmon (Diospyros kaki L.) fruit. Journal of Pharmacognosy and Phytochemistry, 9(4): 3364 - 3367.

Gomez, M.L. and F.M. Lajolo (2008). Ascorbic acid metabolism in fruits: activity of enzymes involved in synthesis and degradation during ripening in mango and guava. Journal of the Science of Food and Agriculture, 88(5): $756-762$.

Holm, G. (1954). Chlorophyll mutations in barley. Acta. Agric. Scandinavica, 4, 457-471.

Homnava, A.; J. Payne, P. Koehler and R. Eitenmilier (1991). Characterization of changes during ripening of Oriental persimmon. Journal of Food Quality, 14(5): 425 - 434.

Kamal, H.M. and M.R. Rabeh (1989). Effect of different ethephon concentrations on ripening of Kaki fruits (Diospyros kaki, L.). Bull. Fac. Agric., Cairo Univ., 40(2): 361 - 378.

Kim, Y.H.; S.C. Lim; C.K. Youn and T.S. Kim (2004). Effects of ethephon on fruit quality and maturity of 'Tone Wase' astringent persimmon (Diospyros kaki. L). Acta Hort., 653: 187 - 191.

Kou, J.; Z. Zhao, W. Wang, C. Wei, J. Guan and C. Ference (2020). Comparative study of ripening related gene expression and postharvest physiological changes between astringent and Non-astringent persimmon cultivars. J. Amer. Soc. Hort. Sci., 145 (3): 203 - 212.

Luo, Z. (2006). Extending shelf-life of persimmon (Diospyros kaki L.) fruit by hot air treatment. Eur. Food Res. Technol., 222: 149 - 154.

Nawito, M.A. (2008). Effect of safe environmental pre and post-harvest treatments and irradiation on handling of some fruits. Ph.D. Thesis, Environmental Science, Department of Agricultural Science, Institute of Environmental Studies \& Research, Ain Shams University, Egypt.

Ramin, A.A. and F. Tabatabaie (2003). Effect of various maturity stages at harvest on storability of persimmon fruits (Diospyros kaki L.). J. Agric. Sci. Technol., 5: 113 - 123.

Rangana, S.H. (1977). Manual of analysis of fruit and vegetable products. Tata McGraw-Hill publishing Company Limited, New Delhi, pp: 634.

Rouhani, I.; A. Nassiri and B. Shaybany (1975). Effect of post-harvest ethephon applications on ripening and physiology of persimmon fruits at various stages of maturity. Journal of Horticulture Science, 50(1): 73 79 . 
Ryerson, N. 1927. Culture of the Oriental persimmon in California. Bull. Calif. Agric. Exp. Sta., No. 416.

Sato, A. and M. Yamada (2016). Persimmon breeding in Japan for pollination-constant non-astringent (PCNA) type with marker-assisted selection. Breed Sci., 66(1): 60 - 68 .

Shiesh, C.C.; H.L. Lin; R.Q. Lin; S.J. Chen and S.P. Feng (2000). Comparative studies of fruit softening in persimmon (Diospyros kaki, Thumb) cv. "Hiratanenshi" in relation to different methods for removal of astringency and temperature. Journal of the Chinese Society for Horticultural Science., 45(3): 273 - 280.

Snedecor, G.W. and W.G. Cochran (1990). Statistical Methods. $7^{\text {th }}$ Ed. Iowa State Univ. Press. Ames., Iowa, USA, p. 593.

Taira, S., N. Masumoto and M. Ono (1999). Differences in solubilities on tannins after six treatments for removal astringency in persimmon fruit. $J$. Japan. Soc. Hort. Sci., 68(1): $83-88$.

Tessmer, M.A.; B.A. Gloria and R.A. Kluge (2016). Astringency in 'Giombo' persimmon and its relationship with the harvest time. Rev. Ceres, Viçosa, 63(5): 646 - 652.

Testoni, A. (2002). Post-harvest and processing of persimmon fruit. In: E. Bellini and E. Giordani (Eds). First Mediterranean Symposium on Persimmon. Ciheam-Iamz. 1:53-70.

Vilhena, N.Q.; R. Gil; E. Llorca; G. Moraga and A. Salvador (2020). Physicochemical and microstructural changes during the drying of persimmon fruit cv. Rojo Brillante harvested in two maturity stages. Foods, 9, 870; doi: 10.3390/foods9070870

Wettstein, D. (1957). Chlorophyll letale und der submikrosko-pische Formwechsel der Plastiden. Exp. Cell Res., 12: 427-434.

Yaqub, S.; U. Farooq, A. Shafi, K. Akram, M.A. Murtaza, T. Kausar and F. Siddique (2016). Chemistry and functionality of bioactive compounds present in persimmon. Journal of Chemistry 16: http:// dx.doi. org/ 10. $1155 / 2016 / 3424025,13 \mathrm{p}$.

Zanamwe, P. (2014). The role of harvest time and maturity, orchard and simulated wind on postharvest quality of 'Triumph' persimmon and the potential of nir as non-destructive sorting tool. M. Sci., Thesis, Fac. Agric. Sci., Stellenbosch Univ., South African. 
تأثير طريقة إزالة المادة القابضة خلال مراحل النضج جودة

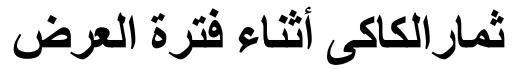

$$
\text { قصم بحوث تداول الفاكهة ـ معهد العزيز بحوث البساتين - مركز البحوث الزر اعية ـ الجيزة- }
$$

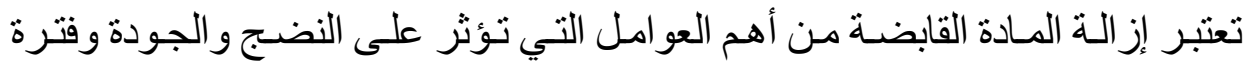
العرض التسويقية لثمار الكاكى. لذللك تم إجر اء هذه الار اسة لتقبيم استخدام كل من الإيثئون

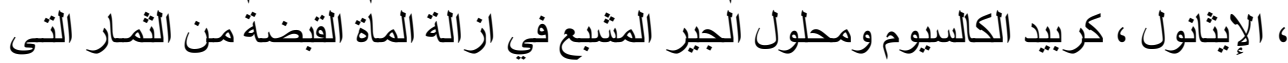

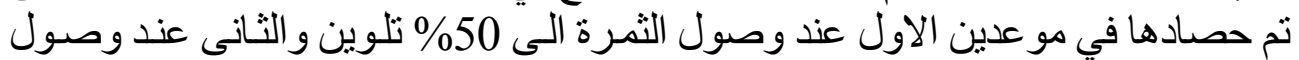

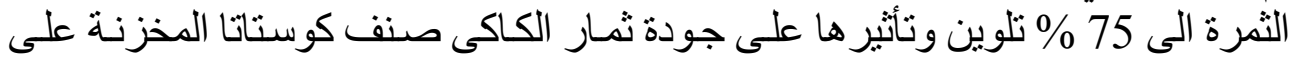

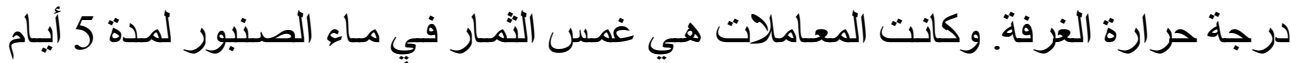

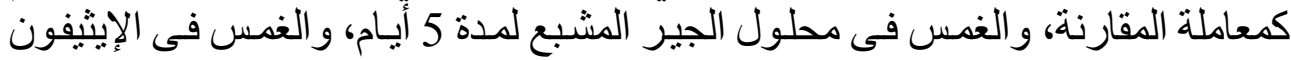

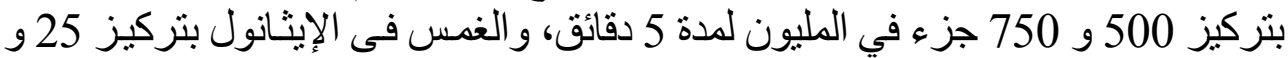

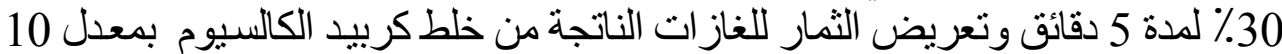

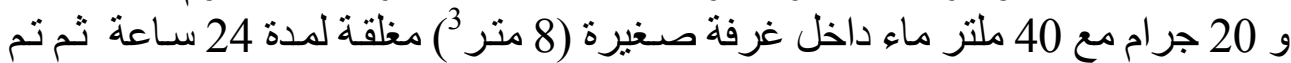

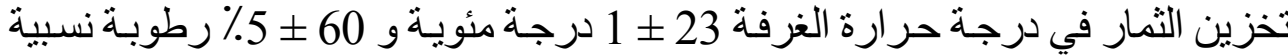
لمدة 15 يومًا.

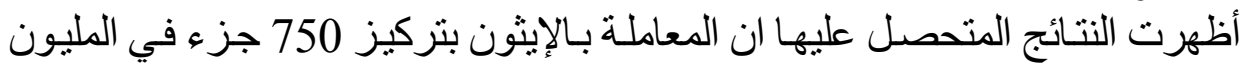

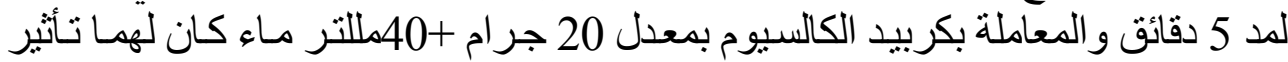

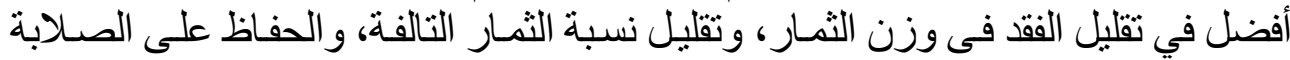

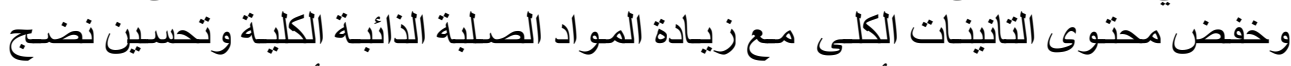

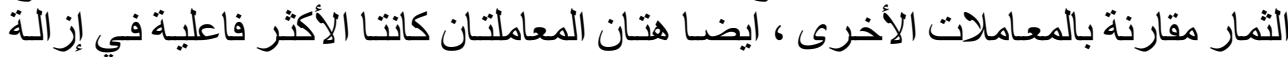

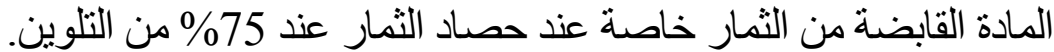

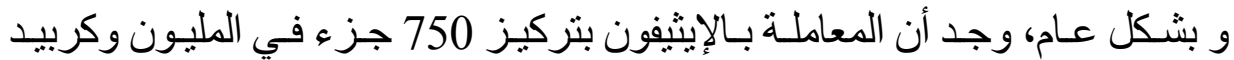

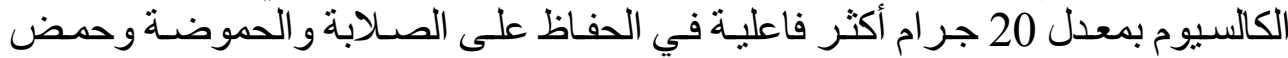

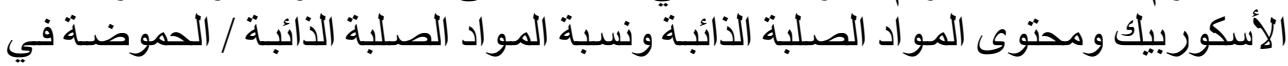
ثمار الكاكى صنف كوستاتا لمدة 15 يومًا واز الة المادة القابضة بغض النظر النظر عن مبعادي الحصاد

التوصية: بمكن التوصية باستخدام احدي المعاملتان المذكورتان سـابقا لازلة المسادة

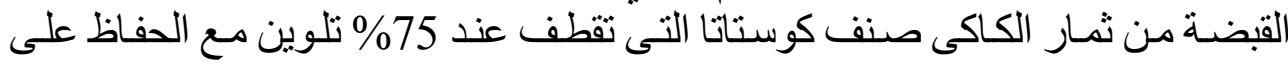
جودة الثمار اثناء فترة العرض. لمن. 